Article

\title{
THE REMOVAL OF RARE-EARTH METALS FROM WATER-SALT SYSTEMS - AN INNOVATIVE ASPECT OF THE MODERN INDUSTRY
}

\author{
Olga Leonidovna Lobacheva ${ }^{1 *}$
}

\author{
1 associate professor of General chemistry department of Saint-Petersburg Mining University; \\ Olga-59@yandex.ru \\ * Correspondence: Olga-59@yandex.ru; Tel.: ((812)+79043304994)
}

\begin{abstract}
Considering the ever-increasing role of rare-earth elements (REE) in the modern hi-tech field, their effective use has a tremendous significance, although the production process is inevitably linked to the large volumes of industrial ammonia effluents and heavy metal wastes. In the process of metallurgical separation of metals, the emission of large volumes of noxious gases and radioactive substances is inevitable. Lean technogenic raw material processing is sensible under the condition of the development of non-waste technology. The lack of competent regulations governing the disposal of waste containing REE has an impact on adjacent territories, accumulating in water bodies and, as a result, in the human body. Such an impact cannot pass without a trace, however, the ambiguity of opinions in the scientific community regarding the toxic effects of REE on living organisms determines the relevance of a more detailed study of this issue. The paper presents experimental and theoretical results of studies of ion flotation in the aqueous solutions containing ytterbium cations and a surfactant as a collector - sodium dodecyl sulphate (NaDS).
\end{abstract}

Keywords: contamination in environmental media 1, ion flotation 2, rare-earth elements 3, removal 4.

\section{Introduction}

The development of REE mineral deposits provokes the leakage of pollutants that pose a danger to human life and health, and severely damages the environment. The rectification of pollution consequences and environmental rehabilitation of territories is topical in the present-day world for the REE mining and production areas [1]. Among the relevant areas of detailed study of the effect of REE on living organisms, the following can be distinguished: the widespread and active use of REE in industry necessitates the study of their physico-chemical properties in order to dispose of hazardous waste containing REE to prevent them from entering the environment and living organisms [2-5]. In particular, to conduct ecological and geochemical zoning and allocation of territories with the presence of anomalies (the presence of REE), Tomsk Polytechnic University conducted studies of the ratio of $\mathrm{La}$ and $\mathrm{Ce}$. The choice of such a material was due to the fact that La and Ce are light REE, and it is they that accumulate in organ tissues and blood plasma, while heavy REE are concentrated mainly in the skeleton. According to the assumptions put forward, toxic elements enter the human body through drinking water, are absorbed into the blood from the gastrointestinal tract and then enter the thyroid gland. Part of the REE is able to linger in the lungs, which can lead to the development of chronic nonspecific inflammatory phenomena such as bronchitis, bronchiolitis, alveolitis, pneumonia [6]. The presence of polar points of view on the effects of REE on the human body serves as the basis for studying this area [7-9].

The paper studies the possibility of lanthanide ions removal from diluted aqueous solutions (as exemplified by yttrium ions) by ion flotation method using NaDS as collector agent [12]. Russia has not less than $20 \%$ of world REE reserves, but the volume of extraction of raw materials is approximately $2 \%$ of world extraction volume [13-17].

To identify the process mechanisms of metal cations removal and separation by ion flotation method, one should know the $\mathrm{pH}$ of metal hydroxo complexes formation and $\mathrm{pH}$ of hydrate formation, calculated based on the Gibbs energies of hydroxo complexes and metal hydroxides formation (Table 1). The $\mathrm{pH}$ value of $\mathrm{Yb}(\mathrm{OH})^{2+}$ hydroxo complexes formation can be calculated based on the expression for instability constants [18]. 
Table 1. Thermodynamic quantities - Gibbs energy of formation of hydrated ions $-\Delta_{f} G_{298}^{0}$ and hydration enthalpy $\Delta_{h y d r} H$ of $\operatorname{Ln}^{+3}$ aq cations [19]

\begin{tabular}{|c|c|c|}
\hline Element & $-\Delta_{f} G_{298}^{0}\left(\mathrm{Ln}^{+3}{ }_{\mathrm{aq}}\right), \mathrm{kJ} / \mathrm{mol}$ & $-\Delta_{\text {hydr }} H\left(\mathrm{Ln}^{+3} \mathrm{aq}\right), \mathrm{kJ} / \mathrm{mol}$ \\
\hline $\mathrm{Tb}$ & 664.18 & 3570 \\
\hline $\mathrm{Dy}$ & 660.92 & 3600 \\
\hline $\mathrm{Ho}$ & 685.89 & 3650 \\
\hline $\mathrm{Er}$ & 670.93 & 3680 \\
\hline $\mathrm{Tm}$ & 670.08 & 3700 \\
\hline $\mathrm{Yb}$ & 644.43 & 3710 \\
\hline $\mathrm{Lu}$ & 631.45 & 3750 \\
\hline
\end{tabular}

A special feature of Russian raw material sources is the REE low content and complex chemical and mineralogical composition. The processing of such raw materials in unprofitable [20-28]. Besides, ore mined at Kola peninsular (a fairly developed Arctic Region in Russia) are used for production of up to 25 concentrates that are different in terms of their composition and properties [29].

The main aim - experimental and thermodynamic study of the possibility of selective REE removal (by the example of $\mathrm{Yb}^{+3}$ ) by an adsorptive bubble separation technique.

\section{Materials and Methods}

According to literature data, an increase of process effectiveness because of valuable components extraction from production wastes is possible when using the ion flotation method in mining industry $[18,20]$. At that, the decrease of REE toxicity, and the risk of damaging the environment, is presumed. In papers $[18,20,22]$ the ion flotation method is proposed for REE removal from apatite sulphuric acid processing products.

\subsection{Ion flotation}

According to data [22] the ion flotation method is used for removal of rare-earth and radioactive metal cations from residential wastewaters. Besides, this method can be used for removal from wastewaters of oil admixtures and petroleum contained in the system [23]. The removal ratio of ion flotation when removing metal cations from the solutions of lean technogenic raw materials processing reaches 100\% [30-33].

\subsection{Process procedure}

The ion flotation was conducted on the flotation machine (figure 1) [31]. $200 \mathrm{ml}$ of ytterbium nitrate solution with the concentration of $0.001 \mathrm{~mol} / 1$ and dry $\mathrm{NaDS}$ were added to the cuvette. The process continued no more than 5 minutes. The formed froth was broken by $5 \mathrm{ml}$ of sulphuric acid solution with the concentration of $1 \mathrm{~mol} \cdot \mathrm{l}^{-1}$. The resulting froth pulp and the solution that remained in the cuvette were analysed for REE content by using method [34] and for dodecyl sulphate ion content by potentiometer method [31].

\subsection{Equipment}

This paper studies the distribution of $\mathrm{Yb}^{+3}$ ions in solutions formed by standardised test solutions containing $\mathrm{Yb}^{+3}$ ions and a surfactant - sodium dodecyl sulphate (NaDS). A flotation machine for ion flotation of lanthanide ions is shown in fig. 1. Critical concentration for micelle formation (CCM) of NaDS is $8 \cdot 10^{-3} \mathrm{~mol} \cdot \mathrm{kg}^{-1}$ at $20^{\circ} \mathrm{C}$ [30]. 


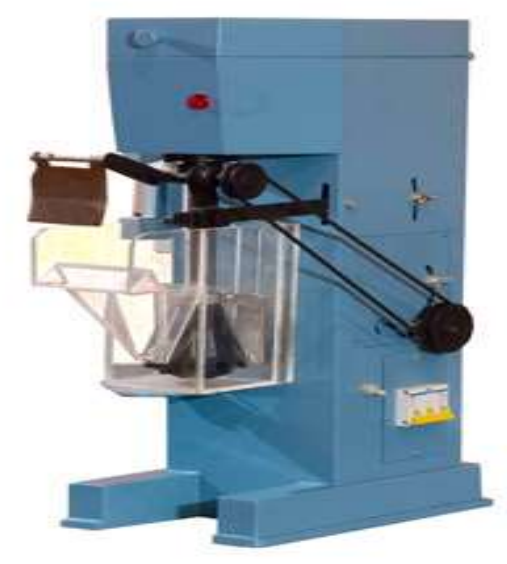

Figure 1. Flotation machine B-ФЛ 137

\section{Experimental and theoretical results}

The results of ion flotation study of the solutions, containing $\mathrm{Yb}^{+3}$ and $\mathrm{DS}-$, are shown in table 2. The ytterbium cations distribution coefficient between water and organic phases was determined by the formula: $K_{\text {distribution }}=C_{o r g} / C_{a q}$.

Table 2. The results of the experimental study of ion flotation in $\mathrm{Yb}^{+3}$ solutions.

\begin{tabular}{|c|c|c|c|}
\hline $\mathrm{pH}$ & $\begin{array}{c}{\left[\mathrm{Yb}^{3+}\right]_{\mathrm{aq}} \cdot 10^{4}} \\
\mathrm{~mol} / 1\end{array}$ & $\begin{array}{c}{\left[\mathrm{Yb}^{3+}\right]_{\text {org }} \cdot 10^{3}} \\
\mathrm{~mol} / 1\end{array}$ & $\begin{array}{c}\text { Distribution } \\
\text { coefficient }\end{array}$ \\
\hline 1.86 & 6.59 & 1.56 & 2.3 \\
\hline 3.00 & 3.40 & 2.03 & 5.9 \\
\hline 3.50 & 3.43 & 2.33 & 6.8 \\
\hline 4.01 & 2.62 & 2.37 & 9.1 \\
\hline 4.60 & 2.73 & 2.24 & 8.2 \\
\hline 5.03 & 2.23 & 2.21 & 9.5 \\
\hline 5.50 & 2.69 & 2.48 & 9.2 \\
\hline 6.00 & 1.79 & 2.46 & 13.8 \\
\hline 6.40 & 0.25 & 2.40 & 95.4 \\
\hline 7.06 & 0.07 & 1.85 & 281.3 \\
\hline 7.38 & 0.05 & 1.96 & 365.3 \\
\hline 8.30 & 0.06 & 2.27 & 403.7 \\
\hline 9.10 & 0.06 & 2.03 & 318.4 \\
\hline
\end{tabular}

From the experimental data shown in the table, one can conclude that the $\mathrm{Yb}^{3+}$ removal doesn't practically take place in acidic mediums. With the increase of $\mathrm{pH}$ value from 4.01 to 5.50 , the distribution coefficient value is just over 9.0. Not surprisingly that in this $\mathrm{pH}$ range neutral and basic ytterbium dodecyl sulphates $\mathrm{Yb}\left(\mathrm{C}_{12} \mathrm{H}_{25} \mathrm{OSO}\right)_{3}$ and $\mathrm{Yb}(\mathrm{OH})\left(\mathrm{C}_{12} \mathrm{H}_{25} \mathrm{OSO}_{3}\right)_{2}$ float. From the resulting experimental data, it's clear that at $\mathrm{pH}$ exceeding 6.00 the distribution coefficient increases rapidly. This value is lower than the $\mathrm{pH}$ value of hydrate formation that was previously determined by us. Consequently, in the $\mathrm{pH}$ range satisfying the maximum removal, ytterbium floats in the hydroxide form with the admixture of neutral and basic dodecyl sulphate.

\section{Discussion}


According to the literature data, in the process of ion flotation of metal cations, the increase in removal occurs in the $p H$ range of hydrate formation [30,31], that is the metal cations passing into froth as hydroxides is observed. In a number of papers $[1,15,18]$ it was discovered that to identify the mechanism of metal cations removal by ion flotation one should know the $p H$ of metal hydroxo complexes and $p H$ of hydrate formation. The $p H$ value of $\mathrm{Yb}(\mathrm{OH})^{2+}$ hydroxo complexes formation is calculated based on the expression for instability constant.

According to the experimental results, the titration curve was plotted as shown in figure 2 .

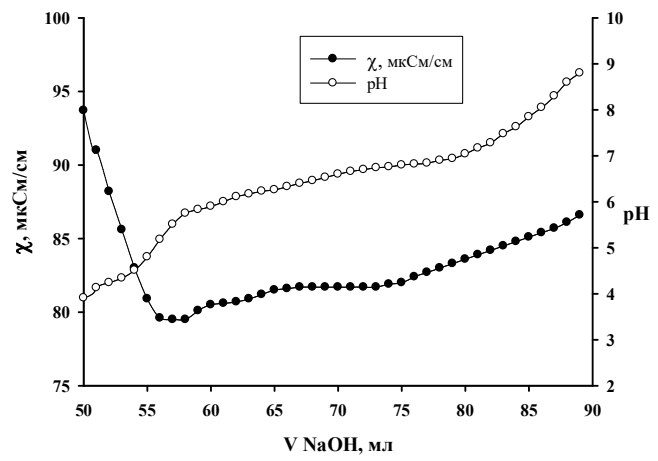

Figure 2. Specific electrical conductivity of $\mathrm{Yb}(\mathrm{NO})_{3}$ solution and $\mathrm{pH}$ as a function of

$\mathrm{NaOH}$ solution volume in the course of conductometric titration.

The Gibbs energy values of $\mathrm{Yb}(\mathrm{OH})_{3}$ formation, specified in the database under the editorship of V.P. Glushko [35] -1268.59 $\pm 3.77 \mathrm{~kJ} / \mathrm{mol}$ and in the handbook [36], agree poorly. In the database [37] this value is missing. The Gibbs energy values of $\mathrm{Yb}(\mathrm{OH})^{2+}$ formation $-832.62 \pm 3.77 \mathrm{~kJ} / \mathrm{mol}$ in the database [35] and -836.29 in [37] agree satisfactory, however they are at odds with the $p H$ of hydrate formation. Calculated by the value [35] $p H_{\text {compl }} 7.7$ is notably higher than $p H_{h y d r}$ that is 6.40 , while the formation of hydroxo complexes should precede the hydroxide sedimentation and take place at lower $p H$ values. Because of inconsistency of values available in the literature data, the evaluation of $p H$ of complex formation and hydrate formation by conductometric titration method was attempted. Titration results were reproduced three times to confirm their reliability.

The calculated values are shown in table 3 . The following areas on the conductometric titration curves are marked out.

1. Up to $60 \mathrm{ml}$ of titrant - a linear drop of specific electrical conductivity is observed, accompanied with the $p H$ rise because of the nitric acid neutralization by alkali.

This section is not mandatory but can be added to the manuscript if the discussion is unusually long or complex.

2. From 62 to $67 \mathrm{ml}$ of titrant - a weak linear growth of specific electrical conductivity is observed, which shows the binding of added hydroxyl anions into a poorly dissociated compound with sodium nitrate accumulation in the solution. Since the formation of hydroxides wasn't observed (optical density of solutions didn't change), this part handles the formation of hydroxo complexes. By the quantity of milliequivalents of alkali spent in this part, one can determine that the process flows until the formation of $\mathrm{Yb}(\mathrm{OH})^{2+}$ monohydroxo complex. $p H=5.50$, conforming to the beginning of this part of the titration curve, was taken as $p H$ of complex formation over the fist stage of $p H_{\text {compl. }}$.

3. Upon the completion of complex formation over the first stage, a surge on the relationship of specific electrical conductivity as a function of titrant volume is observed at 67-68 ml, conditioned by high equivalent conductivity of the added hydroxyl anions. Next, from 68 to $74 \mathrm{ml}$ of titrant - there's an almost horizontal part of the titration curve, attribute to $\mathrm{Yb}(\mathrm{OH})_{2}{ }^{+}$dihydroxo complexes formation. The $\mathrm{pH}=6.00$ conforms to the beginning of complex formation over the second stage.

4. At the titrant volume of $74-75 \mathrm{ml}$ a new electrical conductivity surge with a transition 
to a horizontal part of the titration curve at the titrant volume of $75-86 \mathrm{ml}$ is observed. This part of the titration curve corresponds to the hydroxide sedimentation in accordance with the reaction:

$$
\mathrm{Yb}(\mathrm{OH}) 2^{+}+\mathrm{OH}^{-}=\mathrm{Yb}(\mathrm{OH}) 3 .
$$

The latter was observed visually and confirmed by an increase in the optical density of solutions. The $p H$ value of hydrate formation was 6.50 .

5. Further on the titration curve, the near-linear growth of specific electrical conductivity because of excess alkali was observed.

The solubility product of ytterbium hydroxide was calculated according to the formula:

$$
L=\left[Y b^{3+}\right]\left(10^{p H_{\text {hydr }}-14}\right)^{3} \cdot \gamma_{ \pm}
$$

where ytterbium cation concentration considering aliquot dilution during the titration up to the volume of $85 \mathrm{ml}$ was in the experiment $1.46 \cdot 10^{-4} \mathrm{~mol} \cdot \mathrm{kg}^{-1}$. Ionic strength was calculated considering nitric acid, added to establish an initial $p H$ value of 3.07 , and alkali, added during the titration. The value of $3 \cdot 64 \cdot 10^{-3} \mathrm{~mol} \cdot \mathrm{kg}^{-1}$ was got. The medium ion activity coefficient of ytterbium nitrate was taken equal to the activity coefficient of Lanthanum chloride under this ionic strength - 0.81 [38].

The Gibbs energy of hydroxide formation was calculated according to the equation:

$$
\Delta_{\mathrm{f}} G_{298}^{0}\left\{Y b(\mathrm{OH})_{3}\right\}=\Delta_{f} G_{298}^{0}\left\{Y b_{a q}^{3+}\right\}+3 \Delta_{f} G_{298}^{0}\left\{O H_{a q}^{-}\right\}+R T \ln L
$$

The standard Gibbs energy value of ytterbium ion formation in an aqueous solution was accepted according to the database [35] as $-644.88 \pm 2.93 \mathrm{~kJ} / \mathrm{mol}$.

The resulting values are shown in table 3 . At the same place, the Gibbs energy values of ytterbium $\Delta_{s} G_{298}^{0}$ hydroxide dissolution and Gibbs energies of complex formation $\Delta_{\text {compl }} G_{298}^{0}$ over theof ytterbium $\Delta_{s} G_{298}^{0}$ hydroxide dissolution and Gibbs energies of complex formation $\Delta_{\text {compl }} G_{298}^{0}$ over the following stages:

$$
\begin{aligned}
& \mathrm{Yb}^{3+}+\mathrm{OH}^{-} \leftrightarrow \mathrm{Yb}(\mathrm{OH})^{2+} \\
& \mathrm{Yb}(\mathrm{OH})^{2+}+\mathrm{OH}^{-} \leftrightarrow \mathrm{Yb}(\mathrm{OH})_{2}^{+} \\
& \mathrm{Yb}(\mathrm{OH})_{2}^{+}+\mathrm{OH}^{-} \leftrightarrow \mathrm{Yb}(\mathrm{OH})_{3},
\end{aligned}
$$

Table 3. Thermodynamic characteristics of ytterbium hydroxo compounds.

\begin{tabular}{|l|l|l|l|l|}
\hline Compound & \multicolumn{1}{|c|}{$\Delta_{f} G_{298}^{0}, \mathrm{~kJ} \cdot \mathrm{mol}^{-1}$} & \multicolumn{1}{|c|}{$\begin{array}{c}\Delta_{s} G_{298}^{0}\left(\Delta_{\text {compl }} G_{298}^{0}\right), \\
\mathrm{kJ} \cdot \mathrm{mol}^{-1}\end{array}$} & $\begin{array}{c}p\left(K_{n, z}\right) \\
\left(p H_{\text {compl }}\right)\end{array}$ \\
\hline $\mathrm{Yb}(\mathrm{OH})_{3}$ & $-1266.74 \pm 3.90$ & $-149.81 \pm 2.57$ & $(5.66 \pm 4.50) \cdot 10^{-27}$ & 6.56 \\
\hline $\mathrm{Yb}(\mathrm{OH})^{2+}$ & $-849.17 \pm 3.03$ & $-47.39 \pm 0.77$ & $(4.99 \pm 1.33) \cdot 10^{-9}$ & 5.47 \\
\hline $\mathrm{Yb}(\mathrm{OH})^{+}$ & $-1050.47 \pm 3.22$ & $-43.95 \pm 1.35$ & $(1.61 \pm 0.45) \cdot 10^{-8}$ & 6.08 \\
\hline
\end{tabular}

The obtained Gibbs energy value of ytterbium hydroxide formation agrees well with the database [35], where the value of $-1268.59 \pm 3.77 \mathrm{~kJ} / \mathrm{mol}$ is specified. The Gibbs energy value of ytterbium monohydroxo complex formation differs significantly from the values of $-832.62 \pm 3.77 \mathrm{~kJ} / \mathrm{mol}$ and $-836.29 \mathrm{~kJ} / \mathrm{mol}$, specified in the databases [35-38]. We calculated the $\mathrm{Yb}(\mathrm{OH})^{2+}$ hydroxo complex instability constant according to data [35]. The got value of $3.96 \cdot 10^{-6}$ corresponding to the $\mathrm{pH}$ of complex formation onset that is 7.7. However, according to our data, this value is significantly higher than the $p H$ of hydrate formation, which is contradictory. Data for ytterbium $\mathrm{Yb}(\mathrm{OH}) 2^{+}$dihydroxo complex formation was obtained for the first time.

\section{Conclusions}

1. The study of ytterbium ions removal from aqueous standard test solutions by adsorptive bubble method - ion flotation, was conducted.

2. The experiments showed that when using the ion flotation method, the maximum 
removal of ytterbium (III) was achieved at $\mathrm{pH}=8.30$.

3 . To determine Gibbs energy values of ytterbium (3+) hydroxide, mono- and dihydroxo complexes formation, that are $-1266.74 \pm 3.90 \mathrm{~kJ} \cdot \mathrm{mol}^{-1},-849.17 \pm 3.03 \mathrm{~kJ} \cdot \mathrm{mol}^{-1}$ and $-1050.47 \pm 3.22 \mathrm{~kJ} \cdot \mathrm{mol}^{-1}$ respectively, the conductometric titration method was used. 4. Ytterbium (3+) distribution coefficients as a function of aqueous phase $p H$ value in the process of ion flotation with sodium dodecyl sulphate were derived. The comparison of values of $p H$ of removal with $p H$ of hydrate formation allows to conclude that ytterbium floats as basic dihydroxoytterbium dodecyl sulphate $\mathrm{Yb}(\mathrm{OH})_{2}\left(\mathrm{C}_{12} \mathrm{H}_{25} \mathrm{OSO}_{3}\right)$.

\section{Patents}

Lobacheva O.L., Dzhevaga N.V. Method of separation of holmium (III) and cerium (III) by anionic surfactant from an aqueous solution of their nitrates. RU № 2735017 C1, 27.10.2020

Author Contributions: “Conceptualization, Lobacheva O.L.; methodology, Lobacheva O.L.; software, Lobacheva O.L.; validation, Lobacheva O.L.; formal analysis, Lobacheva O.L., Dzhevaga N.V.; investigation, Lobacheva O.L.; resources, Lobacheva O.L., Dzhevaga N.V.; data curation, Lobacheva O.L.; writing - original draft preparation, Lobacheva O.L.; writing - review and editing, Lobacheva O.L.; visualization, Lobacheva O.L.; supervision, Lobacheva O.L.; project administration, Lobacheva O.L. All authors have read and agreed to the published version of the manuscript."

Funding: “This research received no external funding"

Acknowledgments: The author expresses thanks to Natalia Dzhevaga (Geo-ecology department of Saint-Petersburg Mining University) for her help in preparation of this paper's manuscript.

Conflicts of Interest: "The author declare no conflict of interest."

\section{References}

1. Dzhevaga, N., Lobacheva , O. Reduction in technogenic burden on the environment by flotation recovery of rare earth elements from diluted industrial solutions (2021) Journal of Applied Sciences 11(16),7452.

2. Narkovich, D. V., Baranovskaya, N. V., Koval, E. V., \& Korogod, N. P. (2016). Influence of technogenesis on forming element composition of children's hair. Bulletin of the Tomsk Polytechnic University, Geo Assets Engineering, 327(8), 116-128.

3. Carneiro, M.F.H., Moresco, M., Chagas, G.R., Oliveira Souza, V.C., Rhoden, C., Barbosa, F., Jr., Assessment of trace elements in scalp hair of a young urban population in Brazil (2011) Biological Trace Element Research, 143 (2), pp. 815-824.

4. Pan, Y., Li, H., Trace elements in scalp hair from potentially exposed individuals in the vicinity of the Bayan Obo mine in Baotou, China (2015) Environmental Toxicology and Pharmacology, 40, pp. 678-685

5. Gil, F., Hernandez, A.F., Toxicological importance of human bio-monitoring of metallic and metalloid elements in different biological samples (2015) Food and Chemical Toxicology, 80, pp. 287-297.

6. Popov, V. K., Pasechnik, E. Y., Protsenko, P. I., \& Goncharov, O. Y. (2018). Rare earth element content in groundwater of tomsk water intake. Bulletin of the Tomsk Polytechnic University, Geo Assets Engineering, 329(6), 97-105.

7. Zabrecky, J.M.; Liu, X.-M.; Wu, Q.; Cao, C. Evidence of Anthropogenic Gadolinium in Triangle Area Waters, North Carolina, USA. Water 2021, 13, 1895. https://doi.org/10.3390/w13141895

8. Ge, Q.; Xue, Z.G.; Chu, F. Rare Earth Element Distributions in Continental Shelf Sediment, Northern South China Sea. Water 2020, 12, 3540. https://doi.org/10.3390/w12123540.

9. Liu, Y.; Li, C.; Omar, R.B.; Shi, X.; Zhang, H.; Faiz, N.N. Sediment Sources and Dispersion on the Western Sunda Shelf, Malay Peninsula, Southern South China Sea. Water 2021, 13, 2823. https://doi.org/10.3390/w13202823

10. Litvinova, T. Yttrium and lanthanides metallurgy (2012), Saint Petersburg, 185 p.

11. Cheremisina, O.V., Volkova, O., Litvinova, T.E. Influence of anion nature on acid leaching of silicate minerals and solvent extraction of rare and rare-earth elements (2020) Chemie der Erde, 80 (3), paper № 125507. DOI: 10.1016/j.chemer.2019.04.003

12. F. Sebba Ion flotation. // M. Metallurgy. 1965. 170 p.

13. Matveeva, V., Danilov, A., Pashkevich, M. Treatment of multi-tonnage manganese-containing waste water using vermiculite (2018) Journal of Ecological Engineering, 19 (1), pp. 156-162. DOI: 10.12911/22998993/79416

14. Strizhenok A.V., Ivanov A.V. (2021) Monitoring of Air Pollution in the Area Affected by the Storage of Primary Oil Refining Waste Journal of Ecological Engineering 22(1) 60-67 DOI: 10.12911/22998993/128873

15. Lutskiy, D., Litvinova, T., Ignatovich, A., Fialkovskiy, I. Complex processing of phosphogypsum - A way of recycling dumps with reception of commodity production of wide application (2018) Journal of Ecological Engineering, 19 (2), pp. 221-225. DOI: 10.12911/22998993/83562 
16. Goman, I.V., Oblova, I.S. Analysis of companies' corporate social responsibility as a way to develop environmental ethics for students specialising in oil and gas activity (2018) International Multidisciplinary Scientific GeoConference Surveying Geology and Mining Ecology Management, SGEM, 18 (5.4), pp. 11-18. DOI: 10.5593/sgem2018/5.4/S22.002

17. Machevariani, M.M., Alekseenko, A.V., Bech, J. Complex characteristic of zircon from granitoids of the Verkhneurmiysky Massif (Amur region) (2021) Minerals, 11 (1), № 86, pp. 1-31. DOI: 10.3390/min11010086

18. Lobacheva O.L, Dzhvaga N.V., Danilov A.S. Understanding the regularities of recovering non-ferrous and rare earth metals from standard test solutions by flotation and solvent sublation

19. Non-ferrous metals. 2020 No. 10 pp. 14-19. DOI: $10.17580 /$ tsm.2020.10.02

20. Database of chemicals and compounds: «Chemical Database Schemix» http://www.schemix.ru/downloads.aspx

21. Lokshin E.P., Kalinnikov V.T., Tareeva O.A. Extraction of rare earth elements from industrial products and waste from processing of Khibiny apatite concentrate. Non-ferrous metals. 2012. No. 3. pp. 75-80.21. Chemistry of salts in aqueous solutions: applications, experiments, and theory. Voigt W. Pure and Applied Chemistry. 2011. T. 83. № 5. C. 1015-1030.

22. Quantum-chemical method for selection of a collecting agentto recover zinc and copper (II) cation sin flotation of mine waste waters. Medyanik N.L., Chanturia V.A., Shadrunova I.V. Journal of Mining Science. 2012. T. 48. № 1. C. 167-176.

23. Recovery of copper-ion by flotation with potassium amylxanthate. Ramírez-Serrano B., Coello-Velazquez A.L., Bernardo A., Afif E., Menendez-Aguado J.M. Revista de Metalurgia (Madrid). 2012. T. 48. № 4. C. 254-263.

24. Kazanskaya L F, Smirnova O M, Palomo Á, Pidal I M and Romana M (2021) Supersulfated cement applied to produce lightweight concrete Materials 14(2) 1-14 403 DOI: 10.3390/ma14020403

25. Romashev, A., He, D., Aleksandrova, T., \& Nikolaeva, N. (2021). Technological typomorphic associations in caustobiolites and methods of their extraction. Metals, 11(1), 1-12. doi:10.3390/met11010121

26. Bazhin, V.Y., Aleksandrova, T.A., Kotova, E.L., Suslov, A.P. A modern view of anomalies in the metal groups of the periodic system of D.I. Mendeleev (2019) Journal of Mining Institute, 239, pp. 520-527. DOI: 10.31897/PMI.2019.5.520

27. Kurdiumov V R, Timofeev K L, Maltsev G I and Lebed A B 2020 Sorption of nickel (II) and manganese (II) ions from aqueous solutions Journal of Mining Institute 242 209-217 DOI:10.31897/PMI.2020.2.209

28. Storozhenko, D., Dryuchko, O., Jesionowski, T., Ivanytska, I. Some Physicochemical Aspects of the Preparatory Stages in the Formation of Self-cleaning Photocatalytic Active Coatings for Building Construction Materials (2020). Lecture Notes in Civil Engineering, 73, pp. 285-301.DOI: 10.1007/978-3-030-42939-3_30

29. Nikolaev, A.I., Krivovichev, S.V. Kola Peninsula in solving problems of national arctic materials science (2019) IOP Conference Series: Materials Science and Engineering, 696 (1), статья № 012019. DOI: 10.1088/1757-899X/696/1/012019.

30. R. Lemlich Adsorptive bubble separation techniques. // N.Y. Academic Press. 1972. 344 P.

31. Lobacheva, O., Dzhevaga, N. Rare-earth elements recovery on the example of Europium (III) from lean technogenic raw materials (2017) Journal of Ecological Engineering, 18 (6), pp. 122-126. DOI: 10.12911/22998993/76827

32. Hoseinian F S, Rezai B, Kowsari E, Chinnappan A and Ramakrishna S 2020 Synthesis and characterization of a novel nanocollector for the removal of nickel ions from synthetic wastewater using ion flotation Separation and Purification Technology 240116639 DOI: 10.1016/j. seppur. 2020.116639

33. Grieves R.B., Charewicz W.R. Ion and colloid flotation of Ni, Co and Pt // Separation Science. 1975. Vol.10. N 1. P.77-92.

34. S.B. Savin / Arsenazo III. M.: Atomizdat. 1966. 265 p.

35. Thermal constants of substances. Handbook. Ed. V.P. Glushko/M.: USSR Academy of Sciences. Vol. 1978. 358 p.

36. Lidin R.A., Andreeva A.A., Molochko A.V. // Handbook. Constants of inorganic substances. Ed. "Dvora", M. 2006.

37. HSC Chemistry OutoKumpu Research OY (ver. 4.1.), Pori, Finland.

38. Ravdel A.A., Ponomareva A.M. / Guide of physics.-chemical quantities.2003,240 p. 